\title{
AS FAVELAS NA OBRA DE LIMA BARRETO
}

\section{Romulo Costa Mattos}

Universidade Federal Fluminense

\section{I}

Lima Barreto foi um dos escritores da Primeira República que mais defenderam os moradores das favelas em seus textos. O curioso é que até 1920 o escritor não havia demonstrado muito interesse por tal paisagem. O que o teria levado a dispensar atenção ao tema das favelas a partir desse ano?

Em primeiro lugar, no censo publicado em 1920, foram observados "muitos habitantes em alojamento assaz impróprios e nas mais precárias condições de habitabilidade, tais como (...) casas cobertas de sapé, palhoças, barracões de madeira e até mesmo verdadeiras tocas" (apud: RIBEIRO, 1997: 195,196). Assim, o número de "barracos" na então capital federal era estimado em 2.500 pelos observadores (LOBO, CARVALHO, STANLEY, 1989: 106). Isso porque, entre 1910 e o ano em que tal recenseamento foi divulgado, haviam surgido diversas favelas no tecido urbano carioca, que apresentavam em comum a localização nas encostas dos morros e a proximidade de importantes fontes de emprego. Na década de 1920, o processo de favelização na cidade tornou-se "multidirecional e incontrolável" (ABREU, 1994: 38), tendo sido esse fenômeno incrementado pela compra de lotes pelo trabalhador suburbano para a realização da chamada autoconstrução (RIBEIRO, 1987: 197,198). Portanto, não foi sem razão que Lima Barreto passou a tratar essas moradias como sendo a representação por excelência da pobreza na capital, condição essa que, nos decênios anteriores, reservara às casas de cômodos - conforme é possível verificar em livros como Memórias do Escrivão Isaías Caminha ${ }^{1}$, de 1909 , e Triste Fim de Policarpo Quaresma², publicado em folhetim em 1911 e editado em livro no ano de 1915.

Em segundo lugar, ao longo de 1920, o Correio da Manhã empreendeu uma campanha pela construção de casas populares, na qual empregou discursos

\footnotetext{
${ }^{1}$ BARRETO, Lima (1977). Memórias do escrivão Isaías Caminha. São Paulo: Brasiliense. p. 148.

2 BARRETO, Lima (1956). Triste fim de Policarpo Quaresma. São Paulo: Brasiliense. pp. 132, 133.
} 
bastante pejorativos contra a população que vivia nas habitações coletivas e nas favelas $^{3}$. Dessa forma, não teria sido coincidência o fato de o intelectual boêmio ter tratado dos "casebres" e dos "barracões" quando a questão da habitação explodiu na grande imprensa. Levando-se em consideração a forte rivalidade que havia entre a aludida empresa de comunicação e o escritor ${ }^{4}$ - além, é claro, da própria "função crítica, combatente e ativista" de seus escritos (SEVCENKO, 1999: 162) -, é tentadora a hipótese segundo a qual esse último tenha entrado em franca concorrência com aquele jornal. Nesse caso, o seu objetivo seria o de apresentar uma imagem mais digna dos moradores das favelas.

Em "O Moleque", Lima Barreto enfocou as favelas do subúrbio de Inhaúma, que preservara o seu nome tupi numa época em que a febre modernizadora levava os logradouros da cidade a serem rebatizados com "nomes banais de figurões ainda mais banais" ${ }^{\prime 5}$. Se em sua obra os subúrbios guardariam valores éticos universais pouco praticados no centro e na zona sul por conta da busca pela "civilização"6, o que dizer de um lugar que, além de suburbano, resguardara a sua denominação indígena? No mínimo, que ele portaria uma dimensão cultural altamente resistente, em oposição ao artificialismo reinante naquelas áreas privilegiadas pelos poderes públicos ${ }^{7}$.

Nessa perspectiva, Inhaúma seria um alentado refúgio cultural. Não obstante, esse subúrbio teria outros esconderijos ainda mais protegidos, que guardariam crenças e valores condenados pelo Rio de Janeiro que se civilizava:

\footnotetext{
3 Nessa conjuntura, o colunista e Deputado Federal Costa Rego escreveu: "À exceção de Santa Thereza e da Tijuca, os morros do Rio estão cheios de choupanas, são focos de malandragem, centros preferidos do vício e do crime, sítios onde a polícia tem que desenvolver uma vigilância extenuante". Correio da Manhã. "A necessidade de morar". 20 de março de 1920.

${ }^{4} \mathrm{Em}$ Recordações do Escrivão Isaías Caminha, Lima Barreto criticou duramente o Correio da Manhã e o seu diretor Edmundo Bittencourt. Devido a tal atitude, o escritor tornou-se um nome interdito nas páginas desse periódico, onde trabalhara e publicara, em 1905, o folhetim $O$ subterrâneo do Morro do Castelo (Dantes, 1999). Sobre o processo de inserção do literato no meio intelectual da capital e na imprensa do início do século XX, ver a tese de Botelho (2001).

5 BARRETO, Lima. "O moleque". In: BARRETO, Lima (1961). Histórias e sonhos. São Paulo: Brasiliense. p. 38.

${ }^{6}$ A "civilização" era concebida como sinônimo de se estar o mais de acordo possível com o modelo e as necessidades dos grandes centros, principalmente a França e a Inglaterra (NEVES, HEIZER, 1991: 14). Diretamente dependente da produção de riqueza e da ordem no trabalho, a procura por esse ideal no Brasil teve como entrave a forte presença da herança africana na aparência da população e em seus costumes. Assim, a "busca de uma civilização nos trópicos tornou-se uma poderosa ideologia de dominação de classe e de controle social sobre pessoas e comportamentos distantes dos modelos europeus" (ESTEVES, 2002: 143).

7 É bom frisar que o romancista não idealizava o subúrbio como um paraíso perdido e por muito pouco não demonstrou irritação com os seus vizinhos suburbanos. De acordo com Botelho (2002:56), "Embora compartilhe com eles as modestas condições de vida, [Lima Barreto] não suporta o assédio das crianças a lhe pedirem livros, dos marmanjos que querem cartas para as namoradas, das moçoilas ansiosas por alguns versos e dos poetas incipientes".
} 
Fogem para lá [Inhaúma], sobretudo para os seus morros e escuros arredores, aqueles que ainda querem cultivar a Divindade como seus avós. Nas suas redondezas, é o lugar das macumbas, das práticas de feitiçaria com que a teologia da policia implica, pois não pode admitir nas nossas almas depósitos de crenças ancestrais ${ }^{8}$ (grifo nosso).

Argutamente identificada por Lima Barreto, essa intolerância policial com os resquícios de uma ordem social tida como ultrapassada - dentre os quais figuravam as religiões afro-brasileiras - remetia à conjuntura da Regeneração, que se expressava nos seguintes fatores: a condenação dos hábitos relacionados à sociedade tradicional, a negação da cultura popular, a expulsão das classes pobres do centro da cidade e a promoção do cosmopolitismo (SEVCENKO, 1999: 30).

Vimos que o cronista constatou a abundância das práticas associadas à cultura proveniente dos povos africanos em Inhaúma e em seus morros. O que Chalhoub (1990: 186) definiu como sendo a "cidade negra"9 no Rio de Janeiro da segunda metade do século XIX, na verdade, sobreviveu ao pós-abolição. Se antes ela se espraiava por toda a capital, a gestão reformista de Pereira Passos acabou criando redutos de negros e pobres em geral, que passaram a se concentrar em lugares como a região portuária, a Cidade Nova, os subúrbios e as favelas (ALVITO, 2001: 271).

Outra observação certeira de Lima Barreto foi a de que o "barracão é uma espécie arquitetônica muito curiosa e muito especial àquelas paragens da cidade" 10. De fato, no período de 1920 a 1933, as circunscrições que reuniam a maior quantidade de casas de madeira e "casebres" eram: Engenho Novo, Méier, Piedade, Madureira, Realengo e... Inhaúma. Recuando para o momento de 1906 a 1920, constatamos que o maior índice de crescimento de construções também ocorrera na zona suburbana ou, mais particularmente, nas freguesias de Irajá e, novamente, Inhaúma (RIBEIRO, 1997: 183,196).

Lima Barreto estava atento às transformações espaciais ocorridas no Distrito Federal. O que existe de mais marcante em seu texto é a recusa aos

\footnotetext{
${ }^{8}$ BARRETO, Lima. "O moleque"... pp. 38, 39.

${ }^{9}$ Embora sejamos tributários do simbolismo dessa "cidade negra", Ribeiro (2002: 168) propôs uma cidade em "branco e preto" - mais especificamente, luso-brasileira -, uma vez que os homens brancos (na maioria portugueses) trabalhavam ao lado dos escravos e dos libertos, sendo forte a concorrência no mercado de trabalho. Já Bretas (1997: 73) problematizou a criação pela historiografia de "cidades" (como a "negra") ou "mundos" (como o da "desordem").

10 BARRETO, Lima. "O moleque"... p. 40.
} 
estereótipos relacionados às favelas e aos seus moradores. Assim, esclareceu que o "barracão" não era "a nossa conhecida choupana de sapê e de paredes 'a sopapos'. É menos e é mais. É menos, porque em geral, é menor, com muito menos acomodações; é mais, porque a cobertura é mais civilizada; é de zinco ou de telhas"11. Aqui cabe dizer que, diferenciando o "barracão" da choupana de sapê, o autor aliviava os habitantes da primeira forma habitacional da recorrente associação à população interiorana, cuja imagem podia ser bastante pejorativa nesse período.

Essa comparação ao interior do Brasil através da arquitetura popular assumia um caráter demeritório porque, de acordo com os discursos da classe intelectual, o seu morador típico seria o Jeca Tatu. Lembre-se que, pouco antes de 1920, Monteiro Lobato passara a apresentar essa personagem não mais como o resultado de uma formação mestiça, mas como o fruto de doenças epidêmicas - o que apontava para a importância de uma educação sanitarista (SCHWARCZ, 1993: 249). Certa vez, o médico Castro Peixoto, referindo-se ao aspecto dos morros, declarou: "Para maior irrisão, vêm juntar-se àquele as choças do nosso interior - de sapê e paredes de 'sopapo', ou seja, as mesmas em que por lá vivem os nossos Jecas, como se prolongassem até aqui o seu habitat"12.

Negar a unidade de formas entre as casinhas de sapê e os "barracões" podia trazer benefícios simbólicos aos habitantes desses últimos, que, dessa maneira, eram poupados dos estereótipos segundos os quais viveriam sem cuidados sanitários e não integrariam o mundo civilizado. Essa conclusão, logicamente, não autoriza o pensamento de que Lima Barreto partilhava das visões negativas a respeito dos moradores do interior do Brasil. Tanto que, em 1919, criticara firmemente o arrazoado de Monteiro Lobato sobre a falta de hábitos higiênicos das gentes da roça, ao dizer que esse problema seria antes de natureza econômica e social do que de ordem médica ${ }^{13}$. Vale a pena ressalvar que o escritor carioca mantinha uma relação cordial com o criador do Jeca Tatu... 14

\footnotetext{
11 idem.

12 Correio da Manhã. "Os progressos da favela e a derrubada das nossas matas". 14 de novembro de 1922.

13 BARRETO, Lima. "Problema vital". In: BARRETO, Lima. Bagatelas (1956). São Paulo: Brasiliense. pp. 130-133. (Revista Contemporânea, 22 de fevereiro de 1919).

${ }_{14}$ Uma parte da correspondência entre Lima Barreto e Monteiro Lobato foi analisada na dissertação de Freitas (2003).
} 
$\mathrm{Na}$ continuação da passagem em que diferenciava o "barracão" da choupana de sapê, o intelectual boêmio se dedicou a um expediente comum entre os repórteres, que era a detalhada descrição do primeiro tipo de construção aqui mencionado. Por um lado, essa atitude expressava certo estranhamento: "o 'barracão' é uma espécie arquitetônica muito curiosa". Por outro, significava uma denúncia, o que combinava perfeitamente com a natureza ativista de seus escritos: "Há alguns com dois aposentos; mas quase sempre, (...) só possui um. A cozinha é feita fora, sob um telheiro tosco, um puxado no telhado da edificação, para aproveitar o abrigo de uma das paredes da barraca; e tudo cercado do mais desolador abandono"15.

Mas Lima Barreto afastava-se dos intelectuais da Regeneração por não descrever os "barracões" e os seus moradores de forma homogênea - e na época a generalização em torno das favelas era bem difundida ${ }^{16}$. Quanto ao referido estilo arquitetônico, esclarecia: "Há duas espécies. Em uma, as paredes são feitas de tábuas; às vezes, verdadeiramente tábuas; em outras, de pedaços de caixões". E seguia evitando a uniformização: "O barracão de Dona Felismina era de um só aposento, mas o da vizinha, Dona Emerenciana, tinha dous". A moradia de Antonia, por sua vez, "era a mais modesta: as paredes do seu barraco eram de taipa". Já a Baiana, que era "rica", habitava "uma das poucas casas de tijolo da Rua dos Espinhos"17.

Acima de tudo, o literato evitava criticar a arquitetura de tais moradias. Não encontramos no conto "O Moleque" condenações à suposta promiscuidade, à precária condição sanitária e à presença de contraventores nas favelas - o que é fácil de localizar na grande imprensa ${ }^{18}$. Ao contrário, as personagens subalternas são donas de "uma dignidade superior e universal" (SEVCENKO, 1999: 168, 169), sendo essa característica sublinhada em sua obra. Assim, "Dona Emerenciana era casada com o Senhor Romualdo, servente ou coisa que o valha

\footnotetext{
${ }^{15}$ BARRETO, Lima. "O moleque"... p. 41.

16 Um exemplo de análise generalizante de tais moradias é encontrado em outro comentário do médico Castro Peixoto: "os casebres e barracões que invadem os morros por todos os lados da cidade (...) são horríveis como aspecto, imundos e infectos como habitações humanas e detestáveis como gosto artístico". Correio da Manhã. "Os progressos da...".

17 BARRETO, Lima. "O moleque"... pp. 40 (primeira citação), 41 (segunda e terceira citações) e 42 (terceira citação).

${ }^{18}$ Esses aspectos foram abordados por Evaristo de Moraes, segundo o qual, no Morro de Santo Antonio "se amontoam centenas de desgraçados, esquecidos de todos os preceitos da higiene, vitimados por toda sorte de degradações físicas e morais". Quanto ao Morro da Favela, parte de sua população seria de "vadios, ratoneiros, turbulentos e facínoras". Correio da Manhã. "A habitação". 02 de junho de 1909.
} 
em uma dependência da grande oficina do Trajano. Era preta como Dona Felismina e honesta como ela"19.

Ao dizer que Dona Felismina e Dona Emerenciana eram negras e honestas, o escritor contradizia o reiterado discurso de que os negros e os moradores das favelas, além de desprovidos de moral, pertenceriam às "classes perigosas". Outro ponto interessante foi a inclusão da profissão do Senhor Romualdo em sua apresentação ao leitor. De certo modo, o autor negava que tais pessoas seriam dignas de um processo por vadiagem ${ }^{20}$. Aliás, é notável que a maioria dos habitantes dessa área tomada por "barracões" tivesse uma ocupação profissional 21

Dona Felismina, "respeitada por sua honra e virtude"22, lavava para fora e era dona de uma pequena pensão que seu marido deixara de herança. Esse, por sua vez, trabalhara como guarda-freios da Estrada de Ferro da Central do Brasil, tendo morrido em um desastre - logo, um acidente de trabalho. Colaborador de jornais operários - e simpatizante de idéias socialistas e anarquistas ${ }^{23}$-, Lima Barreto devia saber que uma das principais reclamações contidas naqueles veículos de comunicação referia-se aos acidentes no trabalho - sendo esses um item relevante na experiência da exploração cotidiana vivida pela classe trabalhadora (MATTOS, 2005: 47, 48). Não obstante, a maior parte da população ocupada em transportes concentrava-se nos distritos centrais e também em Inhaúma, onde estavam situadas as oficinas da Central (LOBO, CARVALHO, STANLEY, 1989: 112).

Até a venda local era freqüentada por "carroceiros, verdureiros, carvoeiros, de passagens; habitués do parati, como os há na cidade de chopps, gente sem ter que fazer que não se sabe como vive, mas que vive honestamente; um ou outro degradado da sua condição anterior ou nascimento"

\footnotetext{
19 BARRETO, Lima. "O moleque"... p. 41.

${ }^{20}$ A repressão à vadiagem na Primeira República foi analisada na dissertação de Mattos (1991).

21 O pensamento expresso nos jornais cariocas acerca das favelas era o de que "Moram ali operários, mas muito poucos, sendo a parte maior composta de gente que só trabalha acidentalmente, quando a isso é compelida pela fome". Correio da Manhã. "Atirado ao abismo". 09 de novembro de 1908.

22 BARRETO, Lima. "O moleque"... p. 42.

23 Botelho (2002: 119, 149-159) considerou que o escritor sempre apoiou a causa dos trabalhadores, sendo mais um crítico mordaz do sistema capitalista do que um ideólogo do socialismo ou do anarquismo. Já Montenegro (2006:147) preferiu enfatizar a afinidade do literato com a segunda doutrina política, ao citar a presença de obras de autores anarquistas em sua biblioteca particular e a utilização das chamadas linguagens negadoras, como a paródia, a ironia e a sátira.
} 
${ }^{24}$. Aqui Lima Barreto falava sobre trabalhadores com profissões formais e outros que se entregavam à viração diária, sem utilizar meios ilícitos para se sustentarem. Possivelmente, abordava o que João do Rio chamara de "pequenas profissões exóticas", ao inventariar as diversas ocupações subterrâneas de um Rio de Janeiro desconhecido das elites ${ }^{25}$. Isso porque o trabalho informal em Inhaúma devia ser bastante praticado, levando-se em conta que esse era o distrito da cidade com o maior número de desempregados (LOBO, CARVALHO, STANLEY: 111).

Os indivíduos inativos também foram citados - "um ou outro degradado da sua condição anterior ou nascimento". Nesse trecho, o autor aludia aos ex-escravos e aos negros em geral que não conseguiram vencer as dificuldades advindas do forte preconceito racial existente na capital federal, e que os tornava vítimas preferenciais da teoria da "suspeição generalizada" - sendo essa a essência da expressão "classes perigosas" (CHALHOUB, 1996: 20, 29). Lembremos que, diferentemente do que Lima Barreto pregava nesse conto, a imagem da incapacidade inata do trabalhador negro - que teria sido agravada pelo período do cativeiro - era muito difundida entre as classes dominantes. Assim, a noção de os que negros e os mulatos se encontravam em um estado de anomia no pós-abolição se explicava pela herança do escravismo (cf. SCHWARCZ, 1987).

A discriminação com base na raça foi uma barreira que o protagonista do primeiro romance publicado por Lima Barreto, o escrivão Isaías Caminha, conseguiu ultrapassar após inúmeros desgostos e privações. Talvez a legitimidade do seu discurso residisse na recusa à idealização de que todos os moradores das favelas viveriam o mais de acordo possível com a ideologia do trabalho, nos moldes desejados pelas classes dominantes. Por isso, incluiu em sua história a prostituta Antonia, aquela que morava na casa mais modesta da Rua dos Maricás - nome que alude à presença de habitações construídas com a madeira dessa árvore de pequeno porte. Apesar de sua estigmatizada profissão, essa mulher contava com a ajuda de seus vizinhos: "Todos da Rua dos Maricás (...) conheciam-Ihe a vida, mas com a piedade e compaixão próprias à ternura

\footnotetext{
24 BARRETO, Lima. "O moleque"... p. 44.

25 RIO, João do (Paulo Barreto). "Pequenas profissões". In: RIO, João do (Paulo Barreto). A Alma Encantadora das ruas (1999). São Paulo: Companhia das Letras. p. 90.
} 
do coração do povo humilde pela desgraça, tratavam-na como se outra fosse ela e a socorriam nas suas horas de maiores aflições" ${ }^{26}$.

No trecho acima vemos mais uma característica da obra do literato: as fortes relações de solidariedade existentes entre as camadas pobres. 0 interessante é que somente um homem nas redondezas não perdoava o comportamento da rapariga Antonia, sendo ele o Antunes, o dono daquela venda freqüentada por trabalhadores das mais diversas profissões. Considerava-a simplesmente como "Uma vagabunda". Mas havia uma explicação para o comportamento dissidente do comerciante. Batia em seu peito um "empedernido coração de futuro grande burguês"27. Para entendermos melhor o sentido dessas palavras, devemos lembrar que a moral popular podia funcionar de modo diferente da moral burguesa (cf. ESTEVES, 1989). Portanto, nada mais sugestivo: enquanto os vizinhos humildes da prostituta encontravam-se imersos em uma inegável rede de solidariedade e socorriam essa mulher nos seus momentos de maior dificuldade, o homem que nutria elevadas pretensões burguesas a condenava peremptoriamente.

Não deixa de ser curioso o detalhe de que esse senhor intolerante fosse conhecido como o Antunes, e não Seu Antunes ou Senhor Antunes, como no caso das pessoas pobres. Talvez Lima Barreto tenha achado que esse comerciante com "coração de futuro grande burguês" não merecesse compartilhar a dignidade superior das pessoas simples e altruístas. Esses pronomes de tratamento, que colocavam as personagens nos lugares sociais que lhes eram reservados, pareciam ser o título de nobreza das personagens subalternas, como no caso de Dona Felismina e Dona Emerenciana. Isso não quer dizer que no subúrbio de Inhaúma as relações de solidariedade não superassem as diferenças sociais, principalmente se um indivíduo mais privilegiado tivesse enfrentado desgraças domésticas - como era o caso da história do Coronel Castro, mais conhecido no bairro como Seu Castro.

Esse empregado aposentado da Alfândega simpatizava bastante com o moleque Zeca, a quem admirava pela ajuda que prestava à mãe, Dona Felismina. Certo dia, Seu Castro resolveu segui-lo "até aquele barracão, naquela modesta rua, bordada de um lado e outro de sebes de maricás e de 'pinhão'

\footnotetext{
${ }^{26}$ BARRETO, Lima. "O moleque"... p. 42.

27 idem.
} 
$(\ldots)^{\prime 28}$. Lá chegando, propôs à mulher que colocasse o menino em um asilo, a fim de que esse pudesse aprender a ler e a escrever. Se não bastasse, a mãe poderia trabalhar na casa do próprio benfeitor, sem precisar se matar de tanto labutar:

Titubeou a rapariga e o velho funcionário compreendeu, pois desde há muito já tinha compreendido, na gente de cor, especialmente nas negras, esse amor, esse apego à casa própria, à sua choupana, ao seu rancho, ao seu barracão - uma espécie de protesto de posse contra a dependência da escravidão que sofreram durante séculos ${ }^{29}$.

Aqui Lima Barreto contradizia a tradição de pensamento que apontava para o servilismo e a dependência dos negros, que seriam naturais devido a sua suposta inferioridade racial. Em relação às mulheres negras que residiam em favelas, a sua visão destoava fortemente daquilo que o jornalista Orestes Barbosa defendeu em 1923:

Negras de longas mamas balançando entre quatro trapos de corpinho, com a saia sungada nas nádegas, mostrando toda a perna, passam o dia na tagarelice das vendas sórdidas - que são os bars chics dali - ou nas pocilgas, deitadas em esteiras descosidas, praticando o vício. (...) As amantes dos moradores da Favela vivem, de dia, quase em ociosidade. ${ }^{30}$.

A despeito desse tipo de discurso que colocava as moradoras negras das favelas como indolentes - em outra continuidade da época da escravidão - ou mesmo amásias de malandro, a possibilidade de as mulheres pobres arrumarem serviço com mais facilidade as colocava em posição de relativa independência diante de seus companheiros (CHALHOUB, 2001: 204). Além disso, a utilização do trabalho feminino constituía um elemento fundamental na organização social e na acumulação de riqueza, considerando aqui o trabalho doméstico e a participação no processo produtivo (SOIHET, 1989: 178).

Mencionada pelo cronista de Todos os Santos, a necessidade de independência demonstrada pelos negros era uma característica marcante desde a vigência da escravidão. Chalhoub (1990: 235, 236, 238) decifrou os dois componentes centrais do "viver sobre si" dos cativos: a possibilidade de morar

\footnotetext{
28 BARRETO, Lima. "O moleque"... p. 47.

${ }^{29}$ idem.

30 BARBOSA, Orestes. "A Favela". In: BARBOSA, Orestes. Bambambã (1993). Rio de Janeiro: Secretaria Municipal de Cultura, Turismo e Esportes, Departamento Geral de Documentação e Informação Cultural. p.112.
} 
fora da casa dos senhores e o desejo de certa autonomia nas atividades produtivas às quais se dedicavam. Sendo que senhores, escravizados e magistrados achavam que o "viver sobre si" se ligava à condição de pessoa livre. E o mais importante disso tudo é que, atuando dessa forma, os negros contribuíram para desconstruir os significados sociais que propiciavam a continuidade da escravidão.

Na Primeira República, é possível identificar essa lógica na organização dos trabalhadores negros do porto do Rio de Janeiro. A herança de práticas advindas da escravidão contribuiu para a concretização do ambicioso projeto daquele grupo: a autonomia e o fechamento do mercado de trabalho, através de sindicatos closed shop consolidados. Isso se ligava diretamente ao que os carregadores reivindicavam nos manifestos da greve de 1906: "o direito" e "a nossa liberdade". Nesse caso, o que eles não queriam mesmo era ser vistos como "negrada" - ou seja, "libertos" -, e sim como homens livres no sentido pleno do termo (CRUZ, 2000: 288).

Sem dúvida, a recusa de Dona Felismina era informada por uma longa tradição de valorização da autonomia pelos negros. Apesar da luta cotidiana, ela parecia orgulhosa com o que conquistara, conforme seu nome sugeria. Seja como for, a atitude de Seu Castro, no sentido de visitá-la em seu "barracão", era uma evidente rejeição ao discurso de que as favelas seriam uma "outra cidade" incrustada no Rio de Janeiro. Assim, Lima Barreto driblava um forte estereótipo que se encontrava no mito de origem das favelas ${ }^{31}$.

Uma outra passagem, mais poética, negava a idéia de que os moradores dos "barracões" viveriam alheios às transformações culturais da Primeira República. Vejamos que o sonho do garoto Zeca era o "Engenho de Dentro e o seu cinema": queria "Ter dinheiro, para ir sempre a ele, ver-lhe instantaneamente as 'fitas' que os grandes cartazes anunciavam e o tímpano a soar continuamente insistia no convite de vê-las" ${ }^{\prime 32}$. Esse desejo alimentado pelo menino é significativo: ao privilegiar a velocidade, a ação, a arte cinematográfica

\footnotetext{
31 O nascimento dessa forma dual de se pensar a cidade remonta ao século XIX e aos seus viajantes, que relataram aqui a suposta existência de "dois Brasis". Expressão do abismo entre o mundo urbano brasileiro (do sul e do sudeste) e o mundo tradicional (do nordeste e do norte), essa reflexão encontrou na oposição favela $x$ asfalto uma de suas formas mais duradouras. Assim, os moradores dessa cidade colocada à parte seriam o "outro construído de acordo com o tipo de identidade de cidadão urbano que estava sendo elaborada" (ZALUAR, Alba, ALVITO, Marcos, 1998: 19). Com o lançamento de Os Sertões, em 1902, o litoral $x$ sertão euclidiano fortaleceu a oposição favela $x$ cidade entre nossos intelectuais. (VALLADARES, 2000:12).

32 BARRETO, Lima. "O moleque"... p. 46.
} 
representava as mudanças no ritmo da vida cotidiana, sendo uma das expressões mais fortes da modernidade (SEVCENKO, 1992: 92, 93).

A abordagem de Lima Barreto dos moradores das habitações populares era bem diferente daquela propagandeada pelos entusiastas da "civilização". O protagonista de seu conto se encantava com o cinema, que era um dos símbolos dos tempos modernos. Porém, um cronista como Olavo Bilac, em 1908, preferira falar que "há nesses morros muita gente que nada sabe do que se passa cá em baixo, e cujo espírito só tem como horizonte vital o espaço limitado por duas ou três ladeiras tortuosas ou sujas" (BILAC, 1926: 204).

Não era à toa que esse texto intitulava-se "Fora da vida". Enquanto o "príncipe dos poetas" versava sobre pessoas que viveriam à margem da "civilização" desenvolvida na mais esplendorosa urbs brasileira, Lima Barreto parecia louvar o esforço, a solidariedade e a resistência das classes pobres. No conto analisado, as mulheres negras que viviam naquela parte favelizada de Inhaúma trabalhavam incansavelmente e superavam as dificuldades do dia-a-dia. Aliás, na resistência das personagens afligidas, apareciam "as aspirações através das quais [elas] buscam rumos alternativos para a remodelação da prática social" (SEVCENKO, 1999: 181).

A mãe do sonhador menino Zeca, Dona Felismina, era um exemplo de resistência e solidariedade naquelas redondezas. A competir em termos de respeito e admiração com ela, somente a Baiana ${ }^{33}$, tida como "rica" por ser dona de uma casa feita de tijolo. Isso era raro na Rua dos Espinhos, nome que fazia alusão às condições de vida de seus moradores. Vale assinalar que sua residência fora comprada com o dinheiro proveniente do suor de seu trabalho: "Vendedora de angu, em outros tempos, conseguira juntar alguma cousa e adquirira aquela casita, a mais bem tratada da rua"134. Aqui devemos mencionar a capacidade de economia dos africanos, em especial os minas ${ }^{35}$, que trouxeram

\footnotetext{
${ }^{33}$ Mesmo não sendo chamada de Dona, Baiana era muito estimada no micro-grupo sócio-cultural a que pertencia. Nesse caso, a ausência do pronome de tratamento pode ser explicada pelo fato de que ela era "rica", motivo pelo qual ficava mais distante da vida da gente da rua. Notemos que Baiana era conhecida através de um codinome, o que pode significar que os vizinhos a tratavam com intimidade ou afeição. Ao tentar definir o caráter nacional brasileiro na década de 1930, Sérgio Buarque de Holanda escreveu no ensaio "O homem cordial": "A manifestação normal de respeito em outros povos tem aqui sua réplica (...) no desejo de estabelecer intimidade" (HOLANDA, 1995: 148).

34 BARRETO, Lima. "O moleque"... p. 43.

35 Os membros dessa nação chegaram ao Rio principalmente de Salvador, depois da Revolta dos Malês, em 1835 (SOARES, 2001:355-391). Nos anos 1840, a expressão minas adquirira um
} 
da África Ocidental uma forte tradição mercantil. Certa vez, o alufá Julio Ganan afirmou a João do Rio:

- (...) Africano tem resistência, menino, africano pagou seu corpo. Eu juntei, vintém a vintém, um conto e oitocentos para me comprar e houve escravas, como a mãe de Henriqueta, que juntaram dinheiro para comprar o próprio corpo e mais o das filhas. (...) Trabalhando, nos aluguéis, no café, vendendo santos ou doces na rua e com auxílio do feitiço. (...) Hoje os africanos daquele tempo estão ricos ${ }^{36}$.

Vemos que o comércio de comida no espaço público era uma forma de arrecadação de dinheiro pelos africanos, que tinham como horizonte a compra da alforria. Portanto, Lima Barreto pode ter dado a entender que a sua personagem Baiana estava imersa nessa tradição, uma vez que "em outros tempos" fora vendedora de $\mathrm{angu}^{37}$; e não custa lembrar que figurava entre os projetos não realizados do intelectual a elaboração de uma história da escravidão.

Na biografia dessa migrante negra da Bahia percebemos a valorização dos laços solidariedade, que ultrapassavam as barreiras raciais. Afinal, ela criava uma menina branca que achara embrulhada na rua. Essa característica dos moradores daquela área favelizada de Inhaúma e de seus arredores foi abordada pelo literato em outros momentos do conto. Vemos que a prostituta Antonia era branca e contava com o apoio dos vizinhos, cuja maioria era negra. Assim como Seu Castro era branco e nem por isso deixou de tentar ajudar Dona Felismina e seu filho Zeca, ambos negros. Dona Felismina era ainda simpatizante do espiritismo $^{38}$ e freqüentava as sessões organizadas pelo Seu Frederico, "um antigo colega de seu marido, mas branco, que morava adiante, um pouco acima" 39.

significado especial ligado àqueles que, entre outros fatores, trabalhavam arduamente para obterem sua liberdade (KARASCH, 2000: 64).

36 RIO, João do (Paulo Barreto). "Negros Ricos". In: Gazeta de Notícias. 13 de maio de 1905 (apud: ARANTES, 2005: 117).

37 Soares (2001b: 415) afirmou que as negras minas quitandeiras, com os seus tabuleiros, "seriam o elo decisivo que manteve acesa a chama da cultura mina entre crioulos, cariocas e baianos no Rio de Janeiro da primeira metade do século $\mathrm{XX}^{\prime \prime}$.

38 Ao mencionar o espiritismo, o escritor pode ter insinuado que os moradores das favelas não seguiam apenas as religiões imediatamente associadas à África e, logo, estigmatizadas como bárbaras. Giumbelli (1987) defende a idéia de que o espiritismo teria se subordinado ao monopólio de cura conquistado pela medicina e se aliado ao poder policial para garantir, no campo religioso, 0 seu papel privilegiado em relação ao "baixo" espiritismo, à macumba e ao candomblé - ou seja, aos cultos de origem africana em geral.

39 BARRETO, Lima. "O moleque"... p. 43. 
Ressaltemos que o autor evitou maiores idealizações no tocante à questão racial, tendo lembrado o preconceito de que os afro-brasileiros eram vítimas. Quando a filha postiça de Baiana passava em frente à venda, o caixeiro costumava Ihe falar, em tom de brincadeira: "- Baianinha, tua mãe é negra". Ao que respondia irritada: "- Negra é tu, 'seu' burro!". O menino Zeca, por sua vez, ouvia dos meninos: "ó moleque! - ó moleque! - ó negro - ó gibi!"40. Não por acaso, esse conto intitulava-se "O moleque", que era a forma como os escravos eram conhecidos quando crianças $^{41}$.

Aqui não podemos deixar de citar uma matéria do Correio da Manhã, na qual o moleque era definido pejorativamente como "a flor em botão do bam-bam-bam", que, por sua vez, era o (mais) "valente"42. A diferença entre o moleque do conto do intelectual e o das reportagens da grande imprensa era que o primeiro não tinha o perfil de um futuro malandro, pelo contrário.

O garoto Zeca representava bem o que Lima Barreto queria ressaltar nas crianças das favelas: "Doce, resignado, e obediente", por causa do zelo da mãe, vivia "com a carapinha sempre aparada (...) e com as roupas sempre limpas"43. Se, de acordo com os jornais, os moradores desses espaços seriam perversos devido à influência do meio em que viviam ${ }^{44}$, nada melhor do que a figura de uma criança e de sua sugerida pureza para neutralizar esse discurso pejorativo. Note-se que, nesse caso, o cronista apontava exatamente para os valores transmitidos pela mãe e o contato com os vizinhos ${ }^{45}$.

O escritor sugeria o inverso do que as classes dominantes ditavam acerca da população que residia em "barracões". A maior certeza de que o conto "O Moleque" não foge à marca combativa de sua obra reside na escolha do distrito onde a história se desenvolve: nos anos 1920, Inhaúma reunia o maior número de operários da cidade do Rio de Janeiro. Logo, o fato de que as favelas eram

\footnotetext{
40 ibid. p. 50.

41 Notemos que nesse texto de Lima Barreto há muitas mulheres e crianças. Isso pode ser explicado pelo fato de que Inhaúma era o distrito com o maior número de pessoas do sexo feminino e na fase da infância (LOBO, CARVALHO, STANLEY, 1989:111).

${ }^{42}$ Correio da Manhã. "Na cidade da multidão turbulenta e sofredora". 22 de julho de 1923. Data citada por Abreu (1994:42).

43 BARRETO, Lima. "O moleque"... p. 44.

${ }_{44}$ Era comum o juízo de que tais pessoas cometeriam o mal sem um motivo que o justificasse. Assim, o Morro da Favela seria um "ninho de valentões e vadios, que não atacam para roubar, mas matam-se uns aos outros por qualquer da cá palha, dando assim muito más provas da nossa civilização". Correio da Manhã. "Atirado ao abismo".

45 A esse respeito, Sevcenko (1999: 163,164) concluiu que, sem exceção, "as personagens trazem a marca do seu meio e constituem o objeto privilegiado da crítica social do autor".
} 
locais de residência da classe trabalhadora ganhava cores ainda mais vivas. Em suma, seriam justamente os trabalhadores pobres os primeiros beneficiários daqueles discursos positivos que o autor colocava em vigor no espaço público carioca.

\section{II}

No conto "O moleque", vemos um tipo de abordagem em que as virtudes e as potencialidades humanas dos moradores das favelas eram ressaltadas. Já nas crônicas publicadas na revista Careta, o que havia de mais forte era a crítica aos poderes públicos pelas precárias condições de moradia enfrentadas por tais pessoas. Assim, essas duas perspectivas eram complementares.

Nas páginas do referido maganize, em 1920, Lima Barreto censurou a febre reformista que se instalara na capital na virada da década. Comentou que era impossível abrir um periódico sem se deparar com propostas "de deslumbrantes e custosos melhoramentos e obras" ${ }^{\prime 46}$. De fato, naquele ano, a grande imprensa encampou a campanha promovida pelos empreendedores particulares. Devido à visita do rei belga em setembro e, principalmente, às comemorações do centenário da independência, em 1922, as propostas de intervenção no espaço da cidade pululavam (KESSEL, 2001: 19). Segundo Motta (1992: 49), "Iniciativas são cobradas e atividades sugeridas, eventos considerados indispensáveis e empreendimentos inadiáveis, tudo (ou quase tudo) tendo por cenário a capital da República".

Nesse contexto, o Correio da Manhã escreveu que a preocupação do administrador do Distrito Federal devia ser, antes de tudo, com os embelezamentos naturais e a limpeza da cidade ${ }^{47}$. Citando o exemplo dos ex-prefeitos Pereira Passos e Paulo de Frontin, um repórter do jornal achava que Sá Freire deveria "tomar iniciativas e ter a ação que é indispensável na atual conjuntura, nas vésperas da comemoração da Independência"48.

A comparação do advogado Sá Freire àqueles dois engenheiros/ políticos que haviam comandado grandes obras públicas - refletia a pressão da grande imprensa sobre o primeiro, que prezou o restabelecimento do equilíbrio

\footnotetext{
${ }^{46}$ BARRETO, Lima. "Megalomania". In: BARRETO, Lima. Coisas do Reino de Jambon (1956). São Paulo: Brasiliense. p. 123. (Careta, 28 de agosto de 1920).

${ }^{47}$ Correio da Manhã "Melhoramentos necessários". 24 de abril de 1920.

${ }^{48}$ Correio da Manhã. "A caminho do centenário". 06 de maio de 1920.
} 
financeiro e paralisou as obras iniciadas por Frontin. A sua experiência como prefeito do Rio de Janeiro encerrou-se com uma inesperada renúncia, antes de completar um ano de mandato. O seu substituto, Carlos Sampaio, deu continuidade às grandes intervenções no espaço, dentre as quais se incluía o arrasamento do Morro do Castelo (KESSEL, 2001: 18-22).

De todas as idéias defendidas na grande imprensa, Lima Barreto destacava a futilidade de se construir um prado de corridas no Leblon: "se o artigo fosse assinado, o seu autor merecia ser lapidado pelos miseráveis e pobres que não têm um hospital para se tratar, pelos mendigos e estropiados que não possuem abrigos onde se abrigar"49. Vemos que as suas palavras ficavam mais agressivas ao defender os direitos das classes pobres.

O tema das habitações populares veio à tona com a condenação do cronista à intenção de se arrasar o Morro do Castelo, num período em que a cidade vivia uma grave crise de moradias: "Não há casas, entretanto queremos arrasar o morro do Castelo, tirando habitação de alguns milhares de pessoas" 50 . Realmente, a eclosão da Primeira Guerra Mundial havia encarecido o preço dos materiais importados e reduzido a uma oitava parte o número de construções e reconstruções no Rio de Janeiro. O crescimento populacional e a necessidade de um juro compensador para o capital empregado também haviam contribuído para o aumento do preço dos aluguéis (ELIA, 1984: 120). Ao longo da década de 1920, houve a diminuição do número de prédios no centro da cidade, em decorrência de obras de renovação do espaço construído e da sua especialização como zona comercial (RIBEIRO, 1997: 186).

Lima Barreto mostrava-se abismado com a lógica administrativa do Distrito Federal, tendo em mente o contexto do pós-guerra, que tingia de incertezas o cenário internacional: "O mundo passa por tão profunda crise, e de tão variados aspectos, que só um cego não vê o que há nesses projetos de loucura, desafiando a miséria geral" ${ }^{\prime 51}$. Esse comentário coincide com a análise do panorama econômico realizada por Kessel (2001:22):

O câmbio, desde fevereiro, caíra de 18 para 16 pence por mil-réis; o preço da saca de café continuava em declínio, por conta da superprodução nativa e da recessão americana que começava a se fazer sentida no início de 1920. A situação dos

\footnotetext{
${ }^{49}$ BARRETO, Lima. "Megalomania"... p. 124.

${ }^{50}$ idem.

51 idem.
} 
Estados Unidos, que haviam saído da conflagração como credores do mundo, detentores de metade das reservas mundiais de outro e grandes saldos na balança comercial, era duplamente preocupante: afetava as exportações brasileiras e, diante da prostração dos países europeus, ameaçava prejudicar o aceso do nosso país àquela que se constituía, temporariamente, na única fonte de capitais disponíveis. Em janeiro de 1920, o governo americano havia suspendido os empréstimos governamentais, numa atitude imitada pela banca privada.

Ou seja, no Brasil, os anos de 1920 e 1921 foram de crise, tendo sido fundada nesse último a Carteira de Redescontos, para estimular a economia (LOBO, CARVALHO, STANLEY, 1989: 104). Por fim, Lima Barreto censurou a forma como a remodelação urbana estava sendo planejada e deu a entender que os morros seriam depositários de certa tradição, sem a qual o Rio seria uma outra cidade: "Remodelar o Rio! Mas como? Arrasando os morros... Mas não será mais o Rio de Janeiro; será outra qualquer cidade que não ele"52. Lembremos que, nos anos imediatamente anteriores ao centenário da independência, a discussão sobre a chamada questão nacional começava a tomar vulto e a influenciar os mais diversos intelectuais (cf. MOTTA: 1992).

Nessa perspectiva, o Morro do Castelo - tido como um quisto colonial na moderna área central (BARROS, 2005: 172-175) - seria uma parte essencial da cidade. Ao contrário da opinião de Lima Barreto, um editorial da Careta pregava que o arrasamento da colina seria uma ação "Em prol da raça brasileira": "A última visita do sr. Prefeito ao Morro do Castelo inspirou-lhe sensata expansão no sentido do arrasamento daquele montão de terra que emporcalha com a sua sombra a estética da cidade ${ }^{\prime 53}$. A revista ainda zombava daqueles que viam no morro um símbolo nacional: "É a tradição, o seu monumento, que os contemporâneos não querem deixar demolir, porque hoje representa um símbolo, o caráter dos políticos do Brasil!..." 54. Assim, evidenciava-se a independência do intelectual em relação à grande imprensa ${ }^{55}$.

\footnotetext{
52 idem.

53 Careta. "Looping the loop". 14 de agosto de 1920.

${ }^{54}$ Careta. "Looping the loop". 20 de novembro de 1920.

${ }^{55}$ Os editoriais da Careta que eram críticos ao governo federal conseguiam harmonizar as ambições políticas de seus proprietários com a sempre enérgica atuação do escritor contra os governantes. Quando a revista condenou o aumento da emissão de papel moeda - medida reivindicada pela bancada paulista para garantir os preços do café (CARONE, 1978: p. 48) -, foi logo respaldada por um artigo de Lima Barreto. Careta. "Looping the loop". 18 de setembro de 1920; BARRETO, Lima. "Papel-moeda". In: BARRETO, Lima. Vida Urbana (1956). São Paulo: Brasiliense. pp. 237-238. (Careta, 18 de setembro de 1920). Outro ponto de concordância entre o cronista e o magazine estava no humor como uma vertente crítica da sociedade (cf. VELLOSO, 1996).
} 
No ano de 1921, o alvo predileto de Lima Barreto foi o prefeito Carlos Sampaio, que, além de promover um pensamento dual de cidade, teria optado pelas obras supérfluas em detrimento da construção de habitações populares para os moradores das favelas:

Vê-se bem que a principal preocupação do atual governador do Rio de Janeiro é dividi-lo em duas partes: uma será européia e a outra, a indígena.

Municipalidades de todo o mundo constroem casas populares: a nossa, construindo hotéis chics, espera que, à vista do exemplo, os habitantes da Favela e do Salgueiro modifiquem o estilo das suas barracas. Pode ser...56

A constatação do cronista encontra o seu equivalente acadêmico na observação de Lago (2000: 62), de acordo com a qual, em 1920,

começou a se conformar a área metropolitana do Rio de Janeiro, num padrão de estruturação interna dicotômico, no que se refere às condições urbanas de vida: um núcleo criado para abrigar as camadas de alto poder aquisitivo que pudessem garantir a rentabilidade do capital público e privado investido em equipamentos e serviços urbanos, e uma periferia onde a omissão do Estado definiu seu conteúdo social.

Menos de um mês depois da publicação daquela crônica, Lima Barreto chamou Carlos Sampaio de "O poderoso doutor Matamorros"57, em uma alusão ao seu objetivo de arrasar o Morro do Castelo. O prefeito costumava aparecer nos devaneios do fictício doutor Encerrabodes, que, apesar de ser engenheiro uma categoria bastante influente nesse contexto de consciência urbanizadora ${ }^{58}$-, não tinha vocação para o poder, nem era muito dinâmico, conforme o seu nome dava a entender ${ }^{59}$. Certo dia, essa personagem literária fitou as habitações da região pericentral:

\footnotetext{
56 BARRETO, Lima. "O Prefeito e o povo". In: BARRETO, Lima (1956). Marginália. São Paulo: Brasiliense. p. 117. (Careta, 15 de janeiro de 1921).

57 BARRETO, Lima. "O poderoso doutor Matamorros". In: BARRETO, Lima (1956). Feiras e mafuás. São Paulo: Editora Brasiliense. (Careta, 5 de fevereiro de 1921).

${ }^{58}$ Com esse termo, Stuckenbruck (1996:20) referiu-se à incorporação do ideal de reforma urbana "pelo poder estatal e sua conseqüente objetivação em obras públicas". Quanto aos engenheiros na Primeira República, Rocha (1995: 41-52) analisou a atuação do Clube de Engenharia junto à municipalidade e o seu papel de destaque no cenário político-social da capital da República. Miceli (1979: 38), por sua vez, apontou para a presença do engenheiro no domínio dos estudos sociais na década de 1920. Já Silva (1995) estudou a ação desses atores sociais no referido decênio, como sendo pertencentes ao que chamou de "elite burocrática" do Distrito Federal.

${ }^{59}$ O Doutor Encerrabodes exemplificava aquilo que o literato chamava de "superstição do doutor", uma vez que, mesmo sem talentos, desfrutava da distinção social proveniente dos lacunosos cursos de nível superior (BOTELHO, 2002:177).
} 
Olhei com tristeza as casas do Mangue, as da "Cidade Nova" nas ruas transversais; as do morro da Favela eu apenas entrevia. Pensei de mim para mim: porque não se acabava com "aquilo"? Seria necessário aquele repoussoir para afirmar a beleza dos bairros chamados chics?

Nesse trecho, vemos novamente a crítica do escritor às condições de moradia nas áreas ocupadas pela classe trabalhadora: a Cidade Nova, o Mangue e a Favela. Com o advento da "era das demolições", as periferias próximas ao centro tornaram-se a primeira opção de muitos desabrigados, dada a sua proximidade ao centro da cidade - nem todos podiam morar nos subúrbios devido aos custos do transporte. O intelectual também falou a respeito da desigualdade social refletida nas diferentes paisagens da capital ("Seria necessário aquele repoussoir para afirmar a beleza dos bairros chamados chics?").

Naquela mesma citação podemos notar uma sutileza da narrativa: palavras pejorativas como "olhei com tristeza" e "aquilo" - essa última resumindo as diversas casas populares existentes na região pericentral ganhavam sentido porque eram pronunciadas por um membro das classes dominantes. Entretanto, o doutor Encerrabodes não era um representante típico das camadas altas da população. Tratava-se de um homem sem pretensões ao poder, cujo sonho era criar galinhas. Por isso, ele pôde formular um sentimento de pena ao avistar as moradias dos trabalhadores - ainda que dentro dos limites impostos pelos valores e as percepções das elites.

Utilizando a figura do doutor Encerrabodes, Lima Barreto censurou a exploração realizada pelo pequeno capital imobiliário nas favelas e nos bairros populares: "pus-me a pensar na sorte daqueles que residiam naquelas casas pobres. Certamente, imaginei, pagam aluguéis exorbitantes!"61. Na continuação dessas linhas, tocou no tema da injustiça social, que contrariaria os princípios da República: "Aquilo era uma injustiça e o fundamento da sociedade (tinha lido não sei onde) é a justiça. Se eu estivesse no lugar do Matamorros, já tinha dado um remédio a um tal estado de cousas!"62.

Esse comentário sobre Carlos Sampaio se explicava pelo seu recente veto à lei 371 , de 1920, que concedia incentivos fiscais de competência municipal aos

\footnotetext{
60 BARRETO, Lima. O poderoso doutor... p. 161.

61 ibid. p. 162.

62 ibid. pp. 162, 163.
} 
construtores de casas populares, com base no decreto federal 2.407, de 1911 . Sem os favores cedidos pela prefeitura, os construtores civis não consideravam rentável o investimento nas chamadas habitações higiênicas - o que tornava a iniciativa do governo central inútil (ELIA, 1984: 124, 125; LOBO, CARVALHO, STANLEY, 1989: 108).

Carlos Sampaio temia que a lei 371, de 1920, fomentasse a especulação imobiliária no Rio de Janeiro, numa época em que a preocupação com o valor de troca do solo urbano passava a figurar explicitamente nos planos municipais (Abreu, 1997: 78). Lima Barreto permaneceu atento ao tema das favelas ao longo do ano de 1921. Em "Leitura de jornais", tarefa à qual se dedicava com afinco, mencionou novamente os magníficos "repoussoirs da Favela, do Salgueiro, do Nheco e outros em muitos morros e colinas" da cidade ${ }^{63}$.

Dessa vez, o escritor citou uma reportagem publicada no jornal O Dia, sobre os "extensos aldeamentos de casas construídas com folhas de latas de gasolina, ripas de caixas de batata e caixões de automóveis". Além dessa descrição da arquitetura informal praticada nas favelas, a matéria continha trechos exaltados: "Por essas barracas, que seria impossível de qualificar de casebres, porque nelas nenhum homem rico abrigaria o seu cão de estima, cobra-se de $30 \$$ a $50 \$ 000$ por mês e até mais"64.

Concordando com o periódico O Dia, Lima Barreto louvou a política adotada em Buenos Aires, que, em vez de construir "pistas ou arenas de jogos atléticos", ergueu casas confortáveis com armações de madeira e ferro. Aqui vemos mais um comentário sobre a frivolidade das obras realizadas pelos governantes brasileiros, que ignorariam as ações de interesse geral.

No final da crônica, o intelectual estabeleceu um ponto de contato entre as obras de embelezamento na Zona Sul e o esquecimento dos morros pelos poderes públicos. O abandono das favelas seria o reverso da moeda que refletia o privilégio concedido aos bairros chiques do Distrito Federal:

ela [a administração] não presta atenção nos meios de enfear e emporcalhar ainda mais a Favela, embora os seus propósitos de embelezamento de Copacabana e arredores peçam logicamente, de acordo com a sua doutrina calcatuense, a transformação

\footnotetext{
${ }^{63}$ BARRETO, Lima. "Leitura de jornais". In: BARRETO, Lima. Feiras e mafuás... p. 94. (Careta, 19 de março de 1921).

${ }^{64}$ idem.
} 
daquele e outros morros que circundam a cidade, na coisa mais repugnante deste mundo... ${ }^{65}$

Notemos que, no afã de denunciar uma situação que considerava calamitosa, Lima Barreto reproduziu discursos de ordem estética e higiênica contra os moradores das favelas ("enfear e emporcalhar ainda mais"). Cabe o adendo de que o literato sempre se colocou contra as obras de embelezamento da capital e os pressupostos do higienismo. De qualquer forma, assistimos a uma menção indireta aos suínos, o que não era raro na discussão sobre as habitações populares. O maior cortiço da história da cidade, por exemplo, era conhecido como Cabeça de Porco ${ }^{66}$. Já o então prefeito Xavier da Silveira declarara, em 1901, que as casas do Morro de Santo Antonio eram "verdadeiros chiqueiros, não podendo nelas habitar pessoa alguma"67.

Lima Barreto estava revoltado com a prioridade que os bairros da zona sul vinham recebendo da prefeitura ("os seus propósitos de embelezamento de Copacabana e arredores"). De fato, no curto tempo de janeiro a julho de 1919, a administração Paulo de Frontin alargara e pavimentara a Avenida Atlântica, construíra no desabitado Leblon a atual Avenida Delfim Moreira, fizera o cais da Urca - bairro que estava sendo criado por uma companhia imobiliária - e aumentara a Avenida Niemeyer. O surto de obras públicas nessa área da cidade foi intensificado no período em que Carlos Sampaio esteve no poder (1920-1922). Nesses anos, houve a construção da Avenida Portugal na Urca onde o prefeito concedeu terrenos para serem loteados pela iniciativa privada -, a reconstrução da Avenida Atlântica (castigada por uma forte ressaca), a concessão por permuta do terreno onde hoje se localiza o Jockey Club Brasileiro, na Gávea, e a abertura da Avenida Rui Barbosa, no Flamengo. Essa última realização, que resultou na conclusão da verdadeira Avenida Beira Mar da reforma Passos, exigiu a retirada da população pobre que vivia em "barracões" e "casebres" (ABREU, 1997: 75-77).

O escritor tinha razão ao apontar para a desproporcional preocupação dos poderes públicos com os bairros da zona sul carioca. Mas deixou de dizer que Frontin e Sampaio beneficiaram também o centro da cidade. Seja como for, o

\footnotetext{
65 ibid. p. 96.

66 Esse apelido surgiu porque na entrada do cortiço existia um grande portal em arcada ornamentado com figuras de porco (VAZ, 1986: 30).

67 Correio da Manhã. "Visita do Prefeito". 17 de outubro de 1901. Data citada por Abreu (1994).
} 
recado havia sido dado: os moradores dos subúrbios da zona norte e das favelas estavam sendo esquecidos nesse processo de renovação urbana do Distrito Federal.

Na crônica intitulada "15 de Novembro", Lima Barreto reiterou a idéia de que as favelas seriam espaços por excelência da pobreza. No aniversário da proclamação da República, o cronista foi levado a refletir sobre a delicada situação dos moradores dos morros cariocas:

Isso me acudiu porque topei com as palavras de compaixão do Senhor Ciro de Azevedo pelo estado de miséria em que se acha o grosso da população do antigo Império Austríaco. Eu me comovi com essa exposição do doutor Ciro, mas me lembrei ao mesmo tempo do aspecto da Favela, do Salgueiro e outras passagens pitorescas desta cidade ${ }^{68}$.

O antigo Império Austríaco vivia as graves conseqüências da Primeira Guerra Mundial; logo, lembrar as favelas durante uma palestra sobre esse desmantelado território europeu tinha o seu simbolismo. Lima Barreto continuou condenando o privilégio concedido pela prefeitura à faixa litorânea da capital: "lembrei-me de que o eminente senhor prefeito quer cinco mil contos para a reconstrução da Avenida Beira-Mar, recentemente esborrachada pelo mar" ${ }^{\prime \prime 9}$. 0 escritor estava no encalço de Carlos Sampaio, talvez por ter notado aquilo que as pesquisas acadêmicas revelaram a respeito da administração do engenheiro: "o período (...) nada mais é do que uma outra etapa do processo de depuração da área nobre da cidade de usos e populações não desejadas" (ABREU, 1997: 78).

Pesando na balança a concentração de obras nas áreas visadas pelo capital imobiliário e o descaso com as favelas, o escritor se perguntava: "Não será (...) que a República é o regímen da fachada, da ostentação, do falso brilho e luxo de parvenu, tendo como repoussoir a miséria geral?"770. Aqui o intelectual deixava transparecer sua frustração com tal sistema político, a qual, aliás, era compartilhada com muitos autores da época (SEVCENKO, 1999: 86-93; CARVALHO, 1987: 37). Na obra de Lima Barreto, o criticado presente republicano era geralmente contraposto a um idealizado passado monarquista. Isso se explicava, principalmente, pela sua crença de que as classes dirigentes da

\footnotetext{
68 BARRETO, Lima. "15 de Novembro". In: BARRETO, Lima. Marginália... p. 35. (Careta, 26 de novembro de 1921).

69 idem.

70 idem.
} 
República não portariam um atributo humano fundamental: a solidariedade (BOTELHO, 2002: 79-86) ${ }^{71}$.

\section{III}

Aproveitando o contexto marcado pelos protestos operários ${ }^{72}$, Lima Barreto chamou atenção para a situação dos moradores das favelas. Leitor voraz dos jornais cariocas, o escritor acompanhava atentamente as resoluções acerca da habitação popular na capital federal. Assim, a sua estratégia de argumentação dependia dos rumos que o debate tomava, ao mesmo tempo em que o influenciava.

Em 1920, quando o Correio da Manhã empreendia uma campanha pela construção de habitações higiênicas - na qual o artifício mais utilizado foi a depreciação das favelas -, Lima Barreto mostrava uma outra realidade a respeito de seus moradores. Conforme vimos, esses seriam, acima de tudo, trabalhadores, honestos e solidários. Já em 1921, enquanto a preocupação com as moradias populares perdia força na grande imprensa e o movimento operário era desmantelado pela repressão estatal, as crônicas do intelectual tornavam-se mais ácidas. Lutando para o tema da habitação não cair no esquecimento, criticou o excesso de obras públicas na zona sul, em detrimento de ações que beneficiassem os habitantes das favelas e dos subúrbios ${ }^{73}$.

No conto "O Moleque", o corajoso projeto intelectual de Lima Barreto - em prol de uma sociedade mais democrática, onde a cidadania fosse mais abrangente - resultou em um trabalho pioneiro no tocante às favelas. Publicado em 1920, esse texto antecipou o fortalecimento dos discursos positivos sobre esses espaços no correr da década em que o nacionalismo arrebatou os intelectuais brasileiros ${ }^{74}$. Havia um outro caminho para se pensar as favelas que

\footnotetext{
${ }^{71}$ Quanto à idéia de que o Estado imperial teria sido mais benevolente com as camadas populares, Chalhoub (1996:184) escreveu: "é preciso muita ginástica intelectual e retórica barroca para descrever como 'tolerante' uma classe dominante que escravizava, intimidava e torturava tanto quanto a classe dos escravocratas brasileiros".

72 O ano de 1920 foi o último da fase de maior mobilização da Primeira República, na qual o movimento operário atingiu um alto grau de organização e de consciência de classe. (COSTA, FREITAS, 2004: 141, 144, 145).

73 Entre 1920 e 1922, Lima Barreto citou as favelas em outros textos que não foram analisados neste artigo: BARRETO, Lima. "Augaricus auditae". In: BARRETO, Lima. Histórias e sonhos... p. 109; BARRETO, Lima. "O feminismo invasor". In: BARRETO, Lima. Coisas do reino... p. 71. (A.B.C., 21 de janeiro de 1922); BARRETO, Lima (1956). Clara dos Anjos. São Paulo: Brasiliense. pp. 92, 115.

74 A valorização das favelas nos anos 1920 foi aborda por Zylberberg (1992: 95-119), Abreu (1994: 42, 43), Berenstein Jacques (1995: 185-200) e Mattos (2004: 149-151).
} 
precisava ser mostrado; parafraseando Sevcenko (1999), essa talvez tenha sido uma das missões mais extenuantes desse "mosqueteiro intelectual".

\section{Referências bibliográficas, bibliografia e fontes:}

\section{Jornais e revistas:}

Careta: 1920, 1921.

Correio da Manhã: 1901, 1908, 1911, 1920, 1922, 1923.

\section{Publicações de época:}

BARBOSA, Orestes (1993). Bambambã. 2a edição. Rio de Janeiro: Secretaria Municipal de Cultura, Turismo e Esportes, Departamento Geral de Documentação e Informação Cultural.

BARRETO, Lima (1956). Bagatelas. São Paulo: Brasiliense.

BARRETO, Lima (1956). Coisas do Reino de Jambon. São Paulo: Brasiliense.

BARRETO, Lima (1956). Feiras e mafuás. São Paulo: Brasiliense.

BARRETO, Lima (1961). Histórias e sonhos. 2a edição. São Paulo:Brasiliense.

BARRETO, Lima (1956). Marginalia. São Paulo: Brasiliense.

BARRETO, Lima (1999). O subterrâneo do Morro do Castelo. 3a edição. Rio de Janeiro: Dantes.

BARRETO, Lima (1977). Recordações do escrivão Isaías Caminha. 6 edição. São Paulo: Brasiliense.

BARRETO, Lima (1956). Triste fim de Policarpo Quaresma. São Paulo: Brasiliense.

BARRETO, Lima (1956). Vida Urbana. São Paulo: Brasiliense.

BILAC, Olavo (1926). Ironia e piedade. 3a edição. Rio de Janeiro: Livraria Francisco Alves Editora.

RIO, João do (Paulo Barreto) (1997). A Alma Encantadora das ruas. São Paulo: Companhia das Letras.

\section{Bibliografia}

ABREU, Mauricio de Almeida (1997). Evolução urbana do Rio de Janeiro. $3^{a}$ edição. Rio de Janeiro: IPLANRIO. 
ABREU, Mauricio de Almeida (1994). Reconstruindo uma história esquecida: origem e expansão das favelas no Rio de Janeiro. Espaço \& Debates, São Paulo, v.14, n.37.

ALVITO, Marcos (2001). As cores de Acari. Uma favela carioca. Rio de Janeiro: Editora FGV.

ARANTES, Erika Bastos (2005). O porto negro: cultura e trabalho no Rio de Janeiro dos primeiros anos do século XX. Dissertação (Mestrado em História) Programa de Pós-Graduação em História, Universidade Estadual de Campinas, Campinas.

BARROS, Paulo Cezar de. Do Berço Histórico à Zona Periférica do Centro: velhas formas, novos Castelos. Dissertação (Mestrado em Geografia) - Programa de Pós-Graduação em Geografia, Universidade do Estado Rio de Janeiro, Rio de Janeiro, 2005.

BERENSTEIN JACQUES, Paula (1995). As favelas do Rio, os modernistas e a influência de Blaise Cendrars. Revista Interfaces, Ano 1, n.1. Rio de Janeiro: UFRJ/CLA.

BOTELHO, Denílson (2001). Letras militantes: história, política e literatura em Lima Barreto. Tese (Doutorado em História) - Programa de Pós-Graduação em História, Universidade Estadual de Campinas, Campinas.

BOTELHO, Denílson (2002). A pátria que quisera ter era um mito. O Rio de Janeiro e a militância literária de Lima Barreto. Rio de Janeiro: Secretaria Municipal das Culturas, Departamento Geral de Documentação e Informação Cultural, Divisão de Editoração.

BRETAS Luiz (1997). A guerra nas ruas: povo e polícia na cidade do Rio de Janeiro. Rio de Janeiro: Arquivo Nacional.

CARONE, Edgard (1978). A República Velha (Instituições e classes sociais). 4a edição. Rio de Janeiro/ São Paulo: Difel.

CARVALHO, José Murilo de (1987). Os Bestializados: o Rio de Janeiro e a República que não foi. São Paulo: Companhia das Letras.

CHALHOUB, Sidney (2001). Trabalho, lar e botequim: o cotidiano dos trabalhadores no Rio de Janeiro da Belle Époque. 2a edição. Campinas: Editora da Unicamp.

CHALHOUB, Sidney (1990). Visões da Liberdade. Uma história das últimas décadas da escravidão na Corte. São Paulo: Companhia das Letras. 
CHALHOUB, Sidney (1996). Cidade Febril: cortiços e epidemias na corte imperial. São Paulo: Companhia das Letras.

COSTA, Branno Hocherman Costa; FREITAS, Francisco Josué Medeiros de (2004). Greves e polícia política nas décadas de 1920 e 1930. In: MATTOS, Marcelo Badaró (coord.). Trabalhadores em greve, polícia em guarda: greves e repressão policial na formação da classe trabalhadora carioca. Rio de Janeiro: Bom Texto: Faperj.

CRUZ, Maria Cecília Velasco e (2000). Tradições negras na formação de um sindicato: Sociedade de Resistência dos Trabalhadores em Trapiche e Café, Rio de Janeiro, 1905-1930. Afro-Ásia, Salvador, n. 24.

ELIA, Francisco Carlos da Fonseca (1984). A questão habitacional no Rio de Janeiro da Primeira República: 1889-1930. Dissertação (Mestrado em História) Programa de Pós-Graduação em História, Universidade Federal Fluminense, Niterói.

ESTEVES, Martha (1989). Meninas perdidas: os populares e o cotidiano do amor no Rio de Janeiro da Belle Époque. Rio de Janeiro: Paz e Terra.

ESTEVES, Martha (2002). Civilização. In: VAINFAS, Ronaldo (org.). Dicionário do Brasil Imperial. Rio de Janeiro: Objetiva.

FREITAS, Celi Silva Gomes de (2003). Entre a Vila Quilombo e a Avenida Central: a dupla exterioridade em Lima Barreto. Dissertação (Mestrado em História) Programa de Pós-Graduação em História, Universidade Estadual do Rio de Janeiro, Rio de Janeiro.

GIUMBELLI, Emerson (1997). O cuidado dos mortos: uma história da condenação e legitimação do espiritismo. Rio de Janeiro: Arquivo Nacional.

HOLANDA, Sérgio Buarque de (1996). Raízes do Brasil. 26a edição. São Paulo: Companhia das Letras.

KARASCH, Mary (2000). A vida dos escravos no Rio de Janeiro: 1808 -1850. São Paulo: Companhia das Letras.

KESSEL, Carlos (2001). A vitrine e o espelho: o Rio de Janeiro de Carlos Sampaio. Rio de Janeiro: Secretaria das Culturas, Departamento Geral de Documentação e Informação Cultural, Arquivo Geral da Cidade do Rio de Janeiro. LAGO, Luciana Corrêa do (2000). Desigualdades e segregação na metrópole: o Rio de Janeiro em tempo de crise. Rio de Janeiro: Revan: Fase. 
LOBO, Eulália Maria Lahmeyer, CARVALHO, Lia Aquino, STANLEY, Myrian (1989). Questão habitacional e movimento operário. Rio de Janeiro: UFRJ.

MATTOS, Marcelo Badaró (1991). Vadios, jogadores, mendigos e bêbados no Rio de Janeiro da virada do século. Dissertação (Mestrado em História Social) Programa de Pós-Graduação em História, Universidade Federal Fluminense, Niterói.

MATTOS, Marcelo Badaró (2005). Experiências comuns. Escravizados e livres na formação da classe trabalhadora carioca. Tese de Titularidade - Programa de Pós-Graduação em História, Universidade Federal Fluminense, Niterói.

MATTOS, Romulo Costa (2004). A "aldeia do mal": o Morro da Favela e a construção social das favelas durante a Primeira República. Dissertação (Mestrado em História Social) - Programa de Pós-Graduação em História, Universidade Federal Fluminense, Niterói.

MICELI, Sergio (1979). Intelectuais e Classe Dirigente no Brasil (1920-1945). São Paulo: Difel.

MONTENEGRO, Benjamin (2006). Lima Barreto: escritor, negro e anarquista. In: DOMINICIS, Rafael Borges, AARÃO REIS FILHO, Daniel (org.). História do anarquismo no Brasil (Volume 1). Niterói: EDUFF; Rio de Janeiro: Mauad.

MOTTA, Marly Silva da (1992). A nação faz 100 anos. A questão nacional no centenário da independência. Rio de Janeiro: Ed. da Fundação Getúlio Vargas CPDOC.

NEVES, Margarida de Souza, HEIZER, Alda (1991). 5a edição. A ordem é o progresso: o Brasil de 1870 a 1910. São Paulo: Atual.

RIBEIRO, Gladys Sabina (2002). A liberdade em construção: identidade nacional e conflitos antilusitanos no Primeiro Reinado. Rio de Janeiro: Relume Dumará/ FAPERJ.

RIBEIRO, Luiz Cesar de Queiroz (1997). Dos cortiços aos condomínios fechados. As formas de produção da moradia na cidade do Rio de Janeiro. Rio de Janeiro: Civilização Brasileira: IPPUR, UFRJ: FASE.

ROCHA, Oswaldo Porto (1995). A era das demolições: cidade do Rio de Janeiro: 1870-1920. Rio de Janeiro: Secretaria Municipal de Cultura, Turismo e Esportes, Departamento Geral de Documentação e Informação Cultural, Divisão de Editoração. 
SCHWARCZ, Lilia Moritz (1987). Retrato em branco e negro. Jornais, escravos e cidadãos em São Paulo no final do século XIX. São Paulo: Companhia das Letras. SCHWARCZ, Lilia Moritz (1993). O espetáculo das raças: cientistas, instituições e questão racial no Brasil. São Paulo: Companhia das Letras.

SEVCENKO, Nicolau (1999). Literatura como missão: tensões sociais e criação cultural na Primeira República. $4^{a}$ edição. São Paulo: Brasiliense.

SEVCENKO, Nicolau. Orfeu estático na metrópole: São Paulo, sociedade e cultura nos frementes anos 20. São Paulo: Companhia das Letras, 1992.

SILVA, Lucia Helena Pereira da (1995). Engenheiros, arquitetos e urbanistas: a história da elite burocrática na cidade do Rio de Janeiro, 1920-1943. Dissertação (Mestrado em Planejamento Urbano e Regional) - Instituto de Pesquisa e Planejamento Urbano e Regional, Universidade Federal do Rio de Janeiro, Rio de Janeiro.

SOARES, Carlos Eugenio Líbano (2001). A capoeira escrava e outras instituições rebeldes no Rio de Janeiro (1808-1850). Campinas: Ed. da Unicamp.

SOARES, Carlos Eugênio Líbano (2001b). Comércio, nação e gênero: as negras minas quitandeiras no Rio de Janeiro. 1895-1900. In: SILVA, Francisco Carlos Teixeira da, MATTOS, Hebe Maria, FRAGOSO, João (org.) Escritos sobre História e Educação: homenagem à Maria Yedda Leite Linhares. Rio de Janeiro: MAUAD/ FAPERJ.

SOIHET, Rachel (1989). Condição feminina e formas de violência. Mulheres pobres e ordem urbana 1890 - 1920. Rio de Janeiro: Forense Universitária.

STUCKENBRUCK, Denise (1996). O Rio de Janeiro em questão: o Plano Agache e o ideário reformista dos anos 1920. Rio de Janeiro: Observatório de Políticas Urbanas: IPPUR: FASE.

VALLADARES, Licia (2000). A Gênese da Favela Carioca. A produção anterior às Ciências Sociais. Revista Brasileira de Ciências Sociais, São Paulo, vol. 15, n. 44. VAZ, Lilian Fessler (1986). Notas sobre o Cabeça de Porco. Revista do Rio de Janeiro, Niterói, vol. 1, n. 2.

VELLOSO, Monica Pimenta (1996). Modernismo no Rio de Janeiro: turunas e quixotes. Rio de Janeiro: Editora Fundação Getúlio Vargas.

ZALUAR, Alba, ALVITO, Marcos (1998). Introdução. In: ZALUAR, Alba, ALVITO, Marcos (orgs). Um Século de Favela. Rio de Janeiro: Editora Fundação Getúlio Vargas. 
ZYLBERBERG, Sonia (1992). Morro da Providência: memórias da "favella". Rio de Janeiro: Secretaria Municipal de Cultura, Turismo e Esportes, Departamento Geral de Documentação e Informação Cultural.

Texto recebido em 28/09/2007. 